Article

\title{
Popular Orientalism: Somerset Maugham in Mainland Southeast Asia
}

\author{
Christine Doran \\ School of Creative Arts and Humanities, Charles Darwin University, Darwin NT 0909, Australia; \\ christine.doran@cdu.edu.au \\ Academic Editor: Albrecht Classen \\ Received: 21 December 2015; Accepted: 2 February 2016; Published: 5 February 2016
}

\begin{abstract}
Based on his experiences during a journey through mainland Southeast Asia in 1923, Somerset Maugham wrote a book of colonial travel entitled The Gentleman in the Parlour. As the work of one of the most popular writers of the twentieth century, Maugham's travelogue both expressed and helped to shape contemporary thinking about Southeast Asia and Western imperialism. Focusing especially on his representations of Burma and Cambodia, an analysis is presented of Maugham's book in the light of postcolonial scholarship, especially the theoretical insights developed under the inspiration of Edward Said's Orientalism. Despite its pretensions to be apolitical, Maugham's travel book is shown to be a repository of Western colonial ideas and attitudes, integrally involved in the circulation of the prevailing European discourse of high imperialism. As such, it is a valuable resource for historians and other scholars who wish to understand the way that discourse worked at the level of popular literature.
\end{abstract}

Keywords: Orientalism; British imperialism; Maugham; Burma; Cambodia; travel

\section{Introduction}

Somerset Maugham was one of the most popular authors of the twentieth century. His prodigious literary output, which included novels, short stories and plays as well as travel books, essays and literary criticism, always attracted a large readership and was outstandingly successful in commercial terms. Indeed his popularity as a writer has endured to this day, with his books remaining in print and being read by a wide international public. The general esteem in which Maugham's work was held lent his views on various issues of the day great authority and credibility and, consequently, considerable impact. The extent of Maugham's popular acclaim was an indicator that his attitudes and assessments both reflected and influenced contemporary views on a broad range of issues.

In 1923 Somerset Maugham travelled across mainland Southeast Asia from Myanmar (then Burma) to Vietnam, using a variety of means of transport including riverboat, canoe, pony, rickshaw, car and steamer. He went from Rangoon up the Irrawaddy River to Pagan, then on to Mandalay, crossed the Shan states of eastern Burma into Thailand and travelled south to Bangkok by car and by steamer to Phnom Penh. He visited the monuments of Angkor, went overland to Saigon, and then by boat to Hue, Hanoi and Haiphong in northern Vietnam. At that time Maugham already had a reputation as a great traveller, having previously published travel books on Spain and China [1,2], but this was the most ambitious and arduous journey he ever made. He recorded his experiences and reflections on the journey in a travel book called The Gentleman in the Parlour: A Record of a Journey from Rangoon to Haiphong, first published by William Heinemann of London in 1930, and reissued by Marlowe \& Company in 1989 [3].

The aim of this article is to present an interpretation of Maugham's book of colonial travel, not so much as a travelogue, nor as a personal memoir or a work of literature, but in terms of its relationship 
to the contemporary discourse of British imperialism. The analysis has been influenced especially by the theoretical insights offered by postcolonial scholarship, developed under the inspiration of Edward Said and in particular his seminal book, Orientalism [4]. In his book Maugham explicitly claimed to be uninterested in British imperialism as a political issue. Nevertheless, he was writing as an Englishman travelling through the British colony of Burma, the French colonies of Indochina, which included Vietnam, Cambodia and Laos, and Thailand which, though never colonized outright, was forced to yield significant concessions to Western imperialists. Throughout the book Maugham's attitudes to the colonized Other and thus to imperialism are clearly revealed. The effect of his account was to reinforce imperialist ideology at a time when British power and authority were peaking, though increasingly being challenged by rising nationalist movements in Asia. Maugham's attitudes were consistent with the recurrent images, tropes and assumptions of the discourse of imperialism, as analyzed by Edward Said in Orientalism, as well as by other postcolonial scholars inspired, in different ways, by Said's work. These writers have drawn attention to how representations of the colonial world in literature, art and other forms of cultural production were deeply imbued with the biases, assumptions and values of Western imperialism, including those of race, gender and class.

It is nearly forty years since Edward Said's path-breaking Orientalism was published, and in that period it has generated a vast literature of critical commentary ranging in tone from trenchant criticism and dismissal to laudatory adulation [5,6]. There is not sufficient space here to canvass this extensive and ongoing debate, nor is it necessary to the task at hand. It is worth reflecting, however, that the amount of academic criticism a theoretical contribution produces is a reliable index of its importance, since those that are worthless are usually simply ignored. As well as outright criticism, Said's original ideas have also been expanded and reshaped in creative and significant ways. For example, some important works have developed the gendered dimensions of Orientalism, which Said admitted to having neglected in his original formulation [7-9]. Despite all the controversy concerning the tenets of Orientalism, Said's thought has had an undeniable and continuing impact on literary studies, and indeed on the humanities more broadly. It is the view of this author that the main tenets still have, in the twenty-first century, much to offer in terms of informing literary analysis.

A writer of great popular appeal, Maugham has in general not been given equal acclaim within literary criticism, nor accorded a place within the canon of English literature. However, the prevailing currents of imperial discourse, its widely-shared assumptions and commonplaces, could find expression in the work of relatively minor writers like Maugham just as clearly as in the productions of writers of distinction-perhaps even more so, because expressed more simply and unambiguously. As Gayatri Spivak has argued, the characteristic themes of imperial inscription run continuously through the whole of the colonial literary archive, discernible in the relatively minor productions of "small unimportant folk" as much as in the canonical texts of the "great names" ([10], p. 133). The discourses of imperialism were indeed the products, not of individual giants of thought, but of countless creative workers labouring over, repeating, elaborating, working variations on the major intellectual preoccupations of the period.

In general, The Gentleman in the Parlour has been severely neglected within the field of Maugham scholarship. Most critical work on his oeuvre has focused overwhelmingly on Maugham's fiction; principally his short stories and novels, and to a lesser extent his plays. Maugham is best known for his fiction, so it is not surprising that literary critics have focused in that direction. Of his travel books, it is On A Chinese Screen that has attracted most attention, partly no doubt because of the growing importance of China in world affairs [11,12]. It is the aim of this article to draw attention to a non-fiction work by Maugham that has previously been sorely neglected, to indicate some interpretive directions which it opens up, and to show that for historians and other students of imperialism the works of such popular writers can yield much to closer analysis. 


\section{Discussion}

William Somerset Maugham (1874-1965) was a prolific writer, skilled in a variety of genres; in fact he wrote twenty novels, thirty plays and more than a hundred short stories. Maugham was English, but grew up in Paris until he was ten; he later lived in the south of France from the age of 55 until his death at age 91 . He was 49 when he made the trip through mainland Southeast Asia, accompanied by his partner, Gerald Haxton. By then Maugham was already known as a world traveller, having previously published travel books on Spain and China, as well as many short stories and novels based on his journeying experiences. Of all his many books, The Gentleman in the Parlour was Maugham's favourite.

In 1930, when The Gentleman in the Parlour appeared, Maugham was at the pinnacle of his literary career, at the beginning of what has been referred to as his "golden decade." Even twenty-five years later, in the mid-1950s, Maugham was still regarded as the most popular author of the era ([13], p. 201). This ensured a wide readership for his travel book on mainland Southeast Asia. Consequently his book would have contributed significantly to shaping contemporary images of Southeast Asia among the British reading public.

The structure of the book does not directly reflect the amount of time or effort devoted to the various sections of the journey. Approximately half of the book is devoted to the first segment of his trip, in Burma, including a long section on the Shan states of eastern Burma. The second half of the book covers his time in Thailand, Cambodia and Vietnam; unfortunately Maugham did not visit Laos, the most frequently neglected country of mainland Southeast Asia. In the following analysis the emphasis will be on Maugham's representations of Burma and Cambodia, but also with some revealing side glances at other sections of his travel account.

This was the high point of the colonial era, and during his travels Maugham was accepted everywhere as a member of the European ruling caste. In Burma, for instance, he was accommodated at the bungalows of the Public Works Department, spaced at regular intervals along his route, and where these were not available small houses were built specially for him ahead of his arrival. Furthermore, as Sigmund Freud perceptively pointed out at the time, the military might of the British navy always stood, notionally, behind any British traveller in a foreign country, making travelling for the British, especially for British men, a far more secure undertaking than for the citizens of other nations, and encouraging both a sense of superiority and pride in the greatness of the British empire ([14], p. 112). Maugham was a gentleman traveller, a man of leisure, with sufficient income, time, social resources and political backing to venture wherever the urge took him, and at his own pace. In his own words, he had "ample leisure for the exercise of an idle curiosity" ([3], p. 4). Consequently the general tone of the book is casual and leisurely. The approach is rambling, giving the impression that there is ample time for digressions, detours, and imaginative excursions off the beaten path.

One of the notable features of the tradition of Orientalist literature was that in their works authors did not direct their focus principally to the Eastern lands in which their work was set ([15], pp. 87-99). Often this is even acknowledged explicitly as a caveat to readers that they will find in the work no objective representation of that foreign locale. So it was with Maugham, who warns his reader thus: "So that the reader of these pages may be under no misapprehension, I hasten to tell him that he will find in them little information" ([3], p. 12). He made fun of a figure of his invention, the Historian of the British Empire. Maugham makes out that this mythical historian would be very critical of Maugham's book because it has little to say about the current status and issues of British rule in Burma, and would therefore be of no value to the historian. In response to this imagined criticism, Maugham gestures derisively: "I cock a snook at the historian" of the British Empire ([3], p. 15). Unlike most of the colonial writers discussed in Mary Louise Pratt's book, Imperial Eyes [16], Maugham had little urge to be comprehensive or to include all the useful information about the places he visited. In fact he makes fun of a fellow traveller who obsessively collected data about all the sites he visited. Maugham's travel book shows none of the characteristics of a tourist guide, a source of useful information for other potential travellers in the region. 
In his explicit comments about his aims and intentions in writing the book, Maugham put stress instead on subjective, emotional and stylistic motives. Rather than a method of acquiring knowledge about Southeast Asia, including its inhabitants, Maugham discusses at length his intention to use the journey as a springboard or opportunity for exploring and expressing his subjective feelings and impressions and for reflecting on philosophical questions, that is for the purposes of personal self-development; in that sense the book is more about Maugham than about mainland Southeast Asia. Like other elite travellers of the period, he "sought to make travel a performance of personal style rather than an exercise in learning or engagement" ([17], p. 79). With his stated intention to use the book for experimenting with literary forms, Maugham also made a claim for his book in terms of the aesthetic: Art for Art's sake. Zawiah Yahya's comments about colonial writing reducing Asia to "mere backdrop" can definitely be applied to Maugham's travelogue ([18], p. 64). The finished work shows little interest in or concern for the everyday economic, political or social life of the inhabitants of the regions he traversed. The realities of imperialism, as they were experienced by the colonised peoples of mainland Southeast Asia, are effaced. George Orwell, whose colonial novel Burmese Days was published around the same time as Maugham's book, commented that: "In all novels about the East the scenery is the real subject-matter" ([19], p. 110); and Frantz Fanon added that in this literature the indigenous inhabitants are assimilated to the natural background ([20], p. 201).

In addition to his focus on subjective affective states and their expression in literary forms, Maugham's reading of European authors during the trip was to have a significant effect on his experiences of travel, and thus on his own travel writing. Umberto Eco has emphasized how travellers are deeply influenced by what he calls the "background books" they take with them on their travels, so that they "see the unknown in the light of the already known" ([21], p. 79). Indeed one sign of the resources Maugham had at his command as a gentleman traveller was the large number of books he always carried with him on his journeys. Eco's point, however, goes further:

These need not accompany us physically; the point is that we travel with preconceived notions of the world, derived from our cultural tradition. In a very curious sense we travel knowing in advance what we are on the verge of discovering, because past reading has told us what we are supposed to discover. In other words, the influence of these background books is such that, irrespective of what travelers discover and see, they will interpret and explain everything in terms of these books ([21], p. 71).

Roland Barthes, in his analysis in $S / Z$, added the insight that in addition to the writer the reader also approaches texts through a network of already existing codes, meanings and other texts ([22], pp. 20-21).

At several important junctures Maugham's reading significantly affected his experience of the journey. His immersion in William Hazlitt, Rudyard Kipling, and Henri Mouhot, the French explorer who rediscovered Angkor in the 1860s, was particularly influential. For instance, Maugham relates how he began to read Hazlitt's essays when steaming up the Irrawaddy by boat, on his way from Rangoon to Pagan. And this is where he comes across the phrase which he chose to use as the title of his book, "The Gentleman in the Parlour." Hazlitt wrote, in an essay called "On Going a Journey":

Oh! it is great to shake off the trammels of the world and of public opinion-to lose our importunate, tormenting, everlasting personal identity in the elements of nature, and become the creature of the moment, clear of all ties...and no longer seeking for applause and meeting with contempt, to be known by no other title than the Gentleman in the parlour! ([3], p. 6)

To Maugham, this seemed to sum up all the benefits and pleasures of travelling. For Maugham the title signified his effort to leave himself behind, to claim anonymity and, through travel, to recreate himself anew. To a reader of the present day this title seems amazingly incongruent for a book on travelling in Southeast Asia, as well as strongly redolent of the class and gender positioning which 
were usually taken for granted within the discourse of high imperialism. In this article it will be shown that Maugham was unable to leave the world and public opinion behind, that he instead took with him, along with his many books, a world of ideas, frameworks and presuppositions regarding the colonized territories and peoples of Southeast Asia.

One of the most common literary strategies characteristic of the discourse of Orientalism was the use of the East as a contrastive term to the West. This device of forming binary oppositions between the two cultures was a foundational feature of Orientalism ([4], p. 46), a process Gayatri Spivak has termed "Othering," arguing that Europe "consolidated itself as a sovereign subject by defining its colonies as 'Others'" ([10], pp. 128-33). Numerous examples of this can be found in Maugham's book. For instance, in a discussion of the morality and imaginativeness (or rather lack thereof) of the "Oriental," in this case the peoples of mainland Southeast Asia, Maugham wrote: "It is one of the mistakes that people make to think that the East is depraved; on the contrary, the Oriental has a modesty that the ordinary European would find fantastic." Here the generalized "Oriental" is situated as the Other to the "European" as one of a binary pair of opposites; in this case, unusually within Orientalism, the Oriental appears to emerge from the contrast with a favourable judgement, as modest rather than depraved. However, Maugham went on to complicate that initial impression, suggesting that the absence of depravity or vice might be attributable simply to a lack of imagination:

Vice you must look for in Paris, London, or New York, rather than in Benares or Peking. But whether this is due to the fact that the Oriental, not being oppressed as we are by the sense of sin, feels no need to transgress the rules that during the long course of his history he has found it convenient to make, or whether, as is shown by his art and literature (which after all are only complicated but monotonous variations on a single theme), he is unimaginative, whom [sic] am I to say? ([3], pp. 87-88)

For Maugham Asian modesty was merely a superficial virtue, probably attributable simply to lack of imagination. Even when he seemed to praise the Oriental character, he was bestowing judgment from on high, from a position of superiority. Such contemptuous dismissals of Asian literature and art as in the quotation above were often concomitants of the Orientalist sense of cultural superiority. Thomas Macaulay, for instance, had famously asserted in his Minute on Indian Education of 1835 that a single shelf of a good European library was worth all of the literature of India and Arabia ([23], p. 43). In addition to the supposed lack of imagination in art and literature, Maugham described Southeast Asian music as characterized by "vague monotony" and lacking in energy ([3], p. 113). He also noted monotony and uniformity in Asian styles of dress, which gave "little opportunity for individual taste" ([3], p. 254); this he contrasted to the multifarious gaiety of English styles. Maugham continually measures East and West against each other.

Even in a description of the landscape itself, Orientalist notions and assumptions could become evident. Describing a river along his path, Maugham wrote in terms of Orientalist oppositions:

But you could never have mistaken it for an English river, it had none of the sunny calm of our English streams, nor their smiling nonchalance; it was dark and tragic, and its flow had the sinister intensity of the unbridled lusts of man ([3], p. 139).

In this example the landscape itself is anthropomorphized. It takes on human characteristics, in this case lustful and sinister ones, qualities which were themselves closely associated in popular European thought with Asia and the Orient ([7], p. 19). Similarly, Maugham describes the Burmese sky as blue, though "not with the brilliant, provocative blue of Italy, but with the Eastern blue, which is milky, pale, and languorous" ([3], p. 89). The tendency to see a diametrical opposition between the Occidental and the Oriental "Other" is clear. Thus Maugham could draw exaggerated contrasts between European vice and Asian morality, between sunny English streams and sinister Asian ones, between brilliant European skies and languorous Eastern ones. These contrasts usually worked towards the denigration of the Asian term in the binary. 
Another characteristic trope of Orientalism is the idea that the countries of the Orient were situated outside of history; that they had somehow been left behind by history. Many examples of this process of dehistoricizing Southeast Asia can be found in Maugham's travelogue. Reflecting on his visit to several rural villages in Cambodia, for instance, Maugham was stunned by the lack of historical change: "It was startling to discover how little in a thousand years this life of theirs had changed" ([3], pp. 243-44). How he could be sure of this historical stasis merely by observation is not revealed. He painted a detailed picture of village life, with emphasis on the absence of progress:

They still do the same things with the same utensils. The rice is pounded or husked in the self-same way, and the village shopkeeper offers for sale the same bananas and the same sugar cane on the same tray. These patient, industrious folk carry on the same yolks the same burdens as their ancestors carried so many generations back ([3], p. 243).

It is this way of thinking that Johannes Fabian has characterised as "the denial of coevalness," the holding of the colonised Other outside of historical time [24]. Thus Maugham pictured Cambodia as a sort of land that time forgot: "The centuries have passed leaving no trace upon them, and some sleeper of the Tenth Century, awakening now in one of these Cambodian villages, would find himself at home in the artless round of daily life" ([3], p. 243). The use of the word "artless" suggests a lack of technological development which would exclude Cambodia from participation in the modern world.

Sometimes this denial of the history of the Other was associated with the notion of their vast antiquity. Maugham described Southeast Asian music as sounding like "something immensely old," and as therefore lacking energy and having been worn down by the ages ([3], p. 113). Likewise he emphasized that in dance, the moves, gestures and attitudes "had not changed in a thousand years" ([3], p. 242). He describes the dancers' mask-like faces as impassive, with no emotion or thought disturbing their immobility of expression, since they were bearing "the weight of so long an ancestry" ([3], p. 242). It was not only art forms that were archaic. The human population of Southeast Asia is itself denied "coevalness" with the European observer:

Then it seemed to me that in these countries of the East the most impressive, the most awe-inspiring monument of antiquity is neither temple, nor citadel, nor great wall, but man. The peasant with his immemorial usages belongs to an age far more ancient than Angkor Wat, the Great Wall of China, or the Pyramids of Egypt ([3], pp. 243-44).

When not seen as exceedingly ancient, however, art forms and life forms could be represented as extremely youthful, that is childlike. Writing of the decoration of the palace at Mandalay, Maugham stressed the crudeness and coarseness of the workmanship, but also highlighted the infantile qualities of the art work:

This is not a barbarous art, which has a greater strength and vitality, a more rugged force, but a savage or, if you like, a childlike art; it is in a way trifling and effeminate and it is its roughness ... that gives it character. You have a notion of a people fumbling confusedly with the very beginning of the beautiful, and they are charmed with shining objects as a bushman might be, or a child ([3], p. 34).

Whether he was describing mainland Southeast Asia in terms of great antiquity or as being childlike, Maugham underlined its simple, undeveloped status compared to other countries.

In his work Dipesh Chakrabarty targets what he calls "historicism" as a set of ideas that assisted in buttressing imperialist ideologies. Indeed he states bluntly that "Historicism enabled European domination of the world in the nineteenth century" ([25], p. 7). According to Chakrabarty, the basic ideas embodied in historicism were that the countries colonized by Europe were not yet part of the modern world, and that the pattern of historical development that had taken place in Europe provided the model that all the rest of the world would necessarily have to follow in order to achieve modernity. Underpinning this was a conception of time as linear, and history as evolutionary. In the colonial 
context historicism became a way of saying to the colonised, "not yet;" they were supposedly not yet ready for self-government, in particular. Chakrabarty aptly describes this as being confined to the "waiting room" of history ([25], p. 8). Whether the colonial Other was portrayed as childlike or as immured in the ancient past, the political implications were the same.

In Mandalay Maugham was introduced to an old woman (whom he does not name), who had been appointed as maid of honor to Queen Supayalat (r.1878-1885), the last queen of Burma before the British conquest. Queen Supayalat, like several other female monarchs in Asia on the eve of colonization, has acquired a reputation in history as a wicked, ruthless and murderous ruler ([26], pp. 16-30). On this subject, the old lady informed Maugham that Supayalat was actually "a very nice woman" and that "people had been so unkind about her; all those stories of the massacres she had instigated, stuff and nonsense!" She went on: "I know for a fact that she did not murder more than two or three people at the outside." The old lady faintly shrugged her fat little shoulders, wrote Maugham, and she added: "Two or three people! What is that to make a fuss about? Life is cheap" ([3], p. 36). Thus Maugham's presentation of this incident reinforced the image of Supayalat as a murderous queen, while playing upon another common Orientalist theme - the supposedly low valuation placed upon human life in Oriental or Asian lands.

As well as presenting a dramatic anecdote to enliven his narrative, Maugham here gave some useful first-hand evidence disputing the commonly-accepted historical portrait of Supayalat as a monstrous woman. This evidence would suggest that perhaps she was guilty of arranging for the murder of a few of her political enemies - a common enough form of intrigue at courts all over the world and throughout history. When carried out by a powerful woman, however, as opposed to male counterparts, such actions could easily become the basis of exaggerated depictions of female monstrosity. Such demonization of a female ruler could carry the moral that power in a woman was unnatural and deeply suspect, as well as tapping into assumptions about the cruelties of "Oriental despotism" ([7], p. 19). Although his informant suggested that the accepted image of Supayalat should be overturned, Maugham stepped back from this conclusion. The way Maugham handled this passage worked instead to preserve the historical myth of Supayalat's monstrosity, by means of a gesture towards stereotypical notions of Orientals' lack of respect for human life.

In his book Maugham had recourse to many other characteristic Orientalist devices and tropes. There are numerous examples that could be cited, and here only a few can be mentioned briefly. When Maugham went to Pagan in Burma he visited the famous Ananda temple, where he saw four huge golden Buddhas. His only description of them was that in the "glowing dimness they are inscrutable" ([3], p. 18). The inscrutability of the Oriental "Other" was another well-worn Orientalist cliché. In other parts of his travel account, those covering his experiences in Thailand, Cambodia and Vietnam, a number of Orientalist tropes can be identified, in particular three of those which have long been associated with the darker side of the Southeast Asian environment: those of illness and tropical disease, particularly malaria; of sex; and of drugs, notably opium. When Maugham reached Bangkok, he was laid up with an attack of malaria. This he traced to sleeping one night without a mosquito net, which gave the Anopheles mosquito its chance. Maugham dwelled at length on this enervating experience of tropical disease ([3], pp. 181-83). Even at this time, the 1920s, Bangkok was already associated in the popular imagination with sexual adventures. Maugham told of meeting a Frenchman on the way to Bangkok, who "talked much of the sexual experiences he had had there" ([3], p. 147). At Haiphong in Vietnam Maugham met one of his old school chums, who had become a drug addict after making a fortune smuggling opium in China-a familiar theme in European literature dealing with China and Indochina ([3], p. 276). These are just a few among many examples of Maugham's use of Orientalist images and stereotypes. Therefore, despite himself, Maugham did write a book of value to the historian of imperialism, in that it is a rich and useful source for discerning and analyzing the attitudes and mentality of Europeans during the colonial era.

In one respect Maugham's account stands out from virtually all other British colonial writing of the period: he writes positively of the way the French as colonizers treated their Asian subjects relative 
to the behavior of the British colonials. It was one of the commonplaces of British colonial literature that the French were oppressively bureaucratic and often even brutal in their methods of imposing imperial control. Yet Maugham wrote approvingly of the egalitarianism of the French as contrasted with what he saw as the "insularity" of the British:

The Frenchman has deep down in him a persuasion that all men are equal and that mankind is a brotherhood ... he cannot prevent himself from feeling that the native, black, brown, or yellow, is of the same clay as himself, with the same loves, hates, pleasures and pains, and he cannot bring himself to treat him as though he belonged to a different species ... the Frenchman will sit with the Annamite [Vietnamese], eat with him, drink with him, and play with him. In the market place you will see the thrifty Frenchwoman with her basket on her arm jostling the Annamite housekeeper and bargaining just as fiercely ... whereas the Burmese only respect the English, the Annamites admire the French ([3], pp. 253-54).

Maugham was very unusual in this assessment of the relative merits of the French and British as colonizers. There was always a tendency for nationalist loyalties and rivalries to come to the fore when writers of this period undertook comparative evaluations of the colonies ([27], pp. 321-22). Maugham's upbringing in France and his Francophile tendencies in general probably influenced him in this assessment.

\section{Conclusions}

Several salient points emerge from the preceding discussion. Maugham undertook his journey as a gentleman traveller of the era of high colonialism. This gave him the resources, both material and social, to adopt a leisurely pace and to make frequent detours according to whim, which in turn was reflected in his digressive style of travel writing.

Maugham made it clear early in the book that he did not intend it to be a useful contribution to the literature on the British or European colonies in the East. Rather than producing a work containing objective information about the countries of mainland Southeast through which he travelled, Maugham followed the tradition of much colonial literature in explicitly focusing on subjective matters of personal feeling and impression. In the creation of the book itself, he stated that he planned to use it as an opportunity to explore different literary forms and styles of writing.

In his book Maugham explicitly makes a claim to political disinterestedness. He asserted that he had no intention of producing an account of the European colonies in Asia or an assessment of the state of imperial rule. This was an attempt on Maugham's part to distance his travel account from political engagement, especially with regard to the issue of European imperialism. It has been argued here, however, that far from being apolitical, Maugham's travelogue was deeply enmeshed in the discourse of high imperialism. The discourse of Western imperialism, usually referred to by postcolonial scholars under the rubric of Orientalism, runs consistently through Maugham's book. Maugham's account of his travels through mainland Southeast Asia is replete with the literary devices and images, stereotypes and clichés that were integral to the discourse of Western imperialism in Asia. Despite his intentions to avoid the question of European imperialism, Maugham frequently played upon the recurring themes, and had recourse to many of the well-used tropes of that hegemonic discourse. Maugham thus produced a book of great interest and value to that figure of his raillery, the Historian of empire, who thus has the last word.

Conflicts of Interest: The author declares no conflict of interest.

\section{References}

1. W. Somerset Maugham. The Land of the Blessed Virgin: Sketches and Impressions of Andalusia. London: William Heinemann, 1905.

2. W. Somerset Maugham. On a Chinese Screen: Sketches of Life in China. London: William Heinemann, 1922. 
3. W. Somerset Maugham. The Gentleman in the Parlour: A Record of a Journey from Rangoon to Haiphong. New York: Marlowe and Company, 1989.

4. Edward W. Said. Orientalism: Western Conceptions of the Orient. London: Penguin, 1995.

5. David Spurr. The Rhetoric of Empire: Colonial Discourse in Journalism, Travel Writing, and Imperial Administration. Durham: Duke University Press, 1993.

6. Tahrir K. Hamdi. “Edward Said and Recent Orientalist Critiques.” Arab Studies Quarterly 35 (2013): 130-48.

7. Rana Kabbani. Europe's Myths of Orient. Basingstoke: Macmillan, 1986.

8. Gayatri C. Spivak. “Can the Subaltern Speak?" In Marxism and the Interpretation of Culture. Edited by Cary Nelson and Larry Grossberg. Urbana: University of Illinois Press, 1988, pp. 271-313.

9. Lila Abu-Lughod. Do Muslim Women Need Saving? Cambridge: Harvard University Press, 2013.

10. Gayatri C. Spivak. "Reading the Archives: The Rani of Sirmur." In Europe and Its Others: Proceedings of the Essex Conference on the Sociology of Literature, July 1984. Edited by Francis Barker, Peter Hulme, Margaret Iversen and Diana Loxley. Colchester: University of Essex, 1985, vol. 1, p. 133.

11. Frances Wood. The Lure of China: Writers from Marco Polo to J.G. Ballard. Hong Kong: Joint Publishing/Yale University Press, 2009.

12. Isaac Yue. "W. Somerset Maugham and the Politicisation of the Chinese Landscape." Asiatic 7 (2013): $73-81$.

13. Richard A. Cordell. "Somerset Maugham at Eighty." College English 15 (1954): 201. [CrossRef]

14. Sigmund Freud. Moses and Monotheism. London: Hogarth Press, 1974, p. 112.

15. Roland Barthes. Critical Essays. Translated by Richard Howard. Evanston: Northwestern University Press, 1972, pp. 87-99.

16. Mary Louise Pratt. Imperial Eyes: Travel Writing and Transculturation. London: Routledge, 1992.

17. John Kucich. Imperial Masochism: British Fiction, Fantasy, and Social Class. Princeton: Princeton University Press, 2007, p. 79.

18. Zawiah Yahya. Resisting Colonialist Discourse. Bangi: Penerbit Universiti Kebangsaan Malaysia, 1994 , p. 64.

19. George Orwell. The Road to Wigan Pier. London: Secker and Warburg, 1959, p. 110.

20. Frantz Fanon. The Wretched of the Earth. Harmondsworth: Penguin, 1967, p. 201.

21. Umberto Eco. Serendipities: Language and Lunacy. Translated by William Weaver. London: Phoenix, 1999, p. 79.

22. Roland Barthes. S/Z. Translated by Richard Miller. New York: Hill and Wang, 1974, pp. $20-21$.

23. Leela Gandhi. Postcolonial Theory: A Critical Introduction. St Leonards: Allen and Unwin, 1996, p. 43.

24. Johannes Fabian. Time and the Other: How Anthropology Makes its Object. New York: Columbia University Press, 1983.

25. Dipesh Chakrabarty. Provincializing Europe: Postcolonial Thought and Historical Difference. Princeton: Princeton University Press, 2000, p. 7.

26. Christine Doran. "Fantasy as History: The Invention of Cixi, Empress of China." Femspec 3 (2002): 16-30.

27. Victor R. Savage. Western Impressions of Nature and Landscape in Southeast Asia. Singapore: National University of Singapore Press, 1984, pp. 321-22.

(C) 2016 by the author; licensee MDPI, Basel, Switzerland. This article is an open access article distributed under the terms and conditions of the Creative Commons by Attribution (CC-BY) license (http://creativecommons.org/licenses/by/4.0/). 